\title{
Family members seeking compulsory hospitalization for drug-using members: profile, expectations and needs
}

Familiares que procuram internação compulsória para membros usuários de drogas: perfil, expectativas e necessidades

Familiares que buscan internación forzada para miembros usuarios de drogas: perfil, expectativas y necesidades

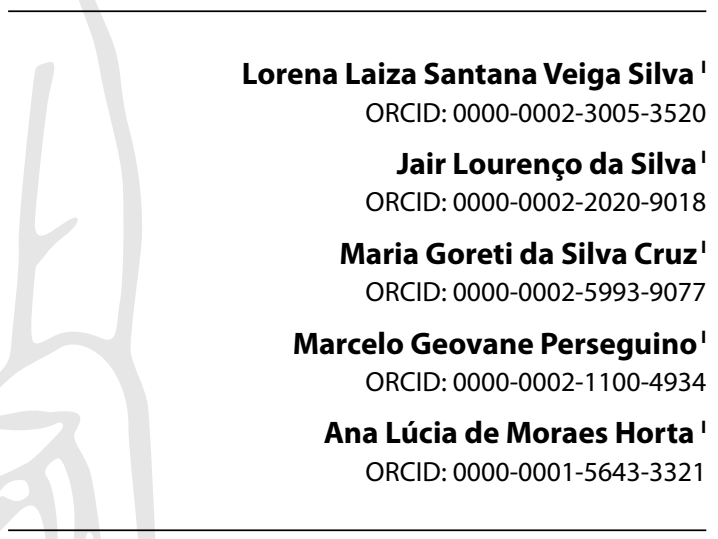

'Universidade Federal de São Paulo. São Paulo, São Paulo, Brazil.

How to cite this article:

Silva LLSV, Silva JL, Cruz MGS, Perseguino MG, Horta ALM. Family members seeking compulsory hospitalization for drug-using members: profile, expectations and needs.

Rev Bras Enferm. 2021;74(4):e20201110. https://doi.org/10.1590/0034-7167-2020-1110

Corresponding author:

Ana Lúcia de Moraes Horta

E-mail: analuciahorta18@gmail.com

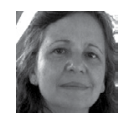

EDITOR IN CHIEF: Antonio José de Almeida Filho ASSOCIATE EDITOR: Fátima Helena Espírito Santo

Submission: 11-07-2020 Approval: 03-06-2021

\begin{abstract}
Objective: to outline the profile and understand the expectations and needs of family members who seek compulsory hospitalization for drug-using members. Method: Mixed research; data collected involving 101 medical records and semi-structured interviews with 26 family members. SPSS software and content analysis was used. Results: The sample was characterized predominantly by women. Most users had other treatment modalities. Significant associations were observed between the request for hospitalization, the presence of aggressiveness, and other behaviors typical of harmful drug use for requesting compulsory hospitalization. The categories were: The difficult coexistence with the user; the journey of family members to "bring the user back to life"; Expectations and needs regarding compulsory hospitalization. Conclusion: The study provided a broader view of the complexity and inter-subjectivities of family systems in the face of the drug cycle, promoting discussions and strategies for multidisciplinary services in the comprehensive care of these families.

Descriptors: Family Relations; Substance Use Disorders; Drug Users; Involuntary Psychiatric Treatment; Right to Health.
\end{abstract}

\section{RESUMO}

Objetivo: Delinear o perfil e compreender expectativas e necessidades de familiares que buscam internação compulsória para membros usuários de drogas. Método: Pesquisa mista; dados coletados envolvendo 101 prontuários e entrevistas semiestruturadas com 26 familiares. Utilizou-se o software SPSS e a análise de conteúdo. Resultados: A amostra caracterizou-se predominantemente por mulheres. A maioria dos usuários realizou outras modalidades de tratamento. Observaram-se associações significantes entre a solicitação da internação, a presença de agressividade e outros comportamentos típicos do uso nocivo de drogas para pedido de internação compulsória. As categorias foram: A difícil convivência com o usuário; O percurso dos familiares para "trazer o usuário de volta à vida"; Expectativas e necessidades quanto à internação compulsória. Conclusão: $O$ estudo proporcionou a ampliação do olhar para a complexidade e intersubjetividades de sistemas familiares diante do ciclo das drogas, promoção de discussões e estratégias de serviços multidisciplinares no cuidado integral dessas famílias. Descritores: Relações Familiares; Transtornos Relacionados ao Uso de Substâncias; Usuários de Drogas; Tratamento Psiquiátrico Involuntário; Direito à Saúde.

\section{RESUMEN}

Objetivo: Delinear perfil y comprender expectativas y necesidades de familiares que buscan internación forzada para miembros usuarios de drogas. Método: Investigación combinada; datos recogidos envolviendo 101 prontuarios y entrevistas semiestructuradas con 26 familiares. Utilizó el software SPSS y el análisis de contenido. Resultados: Muestra caracterizada predominantemente por mujeres. Mayoría de los usuarios realizó otras modalidades de tratamiento. Observaron asociaciones significantes entre la solicitud de la internación, la presencia de agresividad y otros comportamientos típicos del uso nocivo de drogas para solicitud de internación forzada. Las categorías fueron: La difícil convivencia con el usuario; El trayecto de los familiares para "traer el usuario de vuelta a vida"; Expectativas y necesidades cuanto a la internación forzada. Conclusión: Estudio proporcionó la ampliación del mirar a la complejidad e intersubjetividad de sistemas familiares delante al ciclo de las drogas, promoción de discusiones y estrategias de servicios multidisciplinares en el cuidado integral de esas familias.

Descriptores: Relaciones Familiares; Perturbaciones Relacionados al Uso de Sustancias; Usuarios de Drogas; Tratamiento Psiquiátrico Involuntario; Derecho a la Salud. 


\section{INTRODUCTION}

The complexity that involves the abuse of drugs is a social phenomenon that generates high costs for the health and justice systems, because many families turn to the Judicial Power believing that it can guarantee protection and solution for their suffering ${ }^{(1-4)}$.

The compulsory hospitalizations are a resource for drug addicts that family members can resort to through the Judiciary, but it is a complex context, far beyond drug use, since it generates great family suffering, and should thus take into account the unpredictability, inter-subjectivity and recursive characteristic of complex phenomena, which transcend absolute truths, vertical and linear solutions.

In contextualizing how compulsory internment develops, we find that the health and judicial systems seek to take into consideration the risk that the chemical dependent may present to himself or to others ${ }^{(1-5)}$. In the literature review, it was possible to find references that discuss this issue from the perspective of users and a gap in articles that involve family members and show who they are, what they expect and what they want to help their loved ones in the management of drug addiction, especially with regard to the judicialization of health. Given the above, this study sought to answer the following question: What is the profile, expectations and needs of family members who seek compulsory hospitalization for drug-using members?

\section{OBJECTIVE}

To outline the profile and understand the expectations and needs of family members who seek compulsory hospitalization for drug-using members.

\section{METHOD}

\section{Ethical aspects}

The research complied with national and international standards of ethics in research with human beings. It was initiated after approval by the Research Ethics Committee of UNIFESP. It was based on Resolution 466/12.

\section{Theoretical and methodological framework, design and type of study}

Exploratory-descriptive study with a Mixed Method (MM) approach as a methodological reference, which enables multiple strategies to answer the research questions $s^{(6-8)}$. Foi norteado pelas ferramentas Fortalecimento do Relatório de Estudos Observacionais em Epidemiologia (STROBE) e Critérios Consolidados para o Relatório de Pesquisa Qualitativa (COREQ) ${ }^{(9)}$. The literature points out that MM has been used in health research and that it can be a trigger for changes in care policies ${ }^{(10)}$.

\section{Methodological Procedures}

\section{Study Scenario}

The research was conducted at the Public Defender's Office of the State of São Paulo, SP, Brazil, in a unit in the interior of the state. This institution has a multidisciplinary team and provides free legal assistance to people in socioeconomic vulnerability, who have family incomes of up to three minimum wages. The main thread of the intervention is to welcome the family and help them to fully access health care, as a universal right, in order to consider the judicialization of the demand as a measure of exceptionality.

\section{Inclusion and exclusion criteria}

Families with at least one family member in harmful use of drugs who sought assistance from the service to enter the process of compulsory admission were included. Families whose family members who were drug users were missing were excluded.

\section{Paths walked: protocol, source, sample, population, collec- tion, study period, and data organization}

The study was divided into two phases, quantitative and qualitative, and data collection was carried out from February to September 2017. In the first phase, the manual and electronic medical records were surveyed and analyzed to understand who this population is and to be able to fill in, in the qualitative phase, some gaps that the records did not reveal. The data extraction was performed from 101 medical records, which helped to delineate the profile of the population and the information of the families of drug users, with the guiding question: "What is the profile of the family members who sought the service for the compulsory hospitalization of their relative who is a drug user?" Based on these documents, a data extraction form was filled out with the following variables: degree of kinship, education, income, marital status, housing situation, supply of public policies in the territory, conjuncture, and typical behaviors of harmful drug use.

In the qualitative phase, data was collected by means of semi-structured interviews, with random selection of 11 families that were selected from the medical records of the quantitative study, totaling 26 participants. The data was collected by means of semi-structured interviews, carried out by the researcher, a family therapist, in their homes, based on the following guiding questions: "What made you seek the Public Defender's Office? What were your expectations and needs regarding the service?" Telephone contact was made to invite participation, followed by two meetings. In the first, interviews were conducted; and, in the second, data validation was carried out, which legitimized the results of the interviews conducted.

\section{Data analysis}

The quantitative data were analyzed using the statistical software Statistical Package for the Social Sciences (SPSS) - version 22.0. The qualitative data analysis was based on content analysis ${ }^{(11-12)}$. As for the content of the interviews, it was transcribed faithfully/ literally, resulting in analyzed and organized data with a gradual understanding of relevant and essential issues for the objective of this research ${ }^{(11)}$. The anonymity of the family members was preserved by changing their names to precious stones, and the names of the individual members were changed to letters. Since 
this is an MM technique, a cross-reference was made between the quantitative and qualitative data, that is, between the statistical data and the life stories found.

\section{RESULTS}

The results showed that the family members of drug users who seek the Public Defender's Office have the following profile: the majority are women (85.1\%); average age of 56.14 years; married (43.6\%); with complete or incomplete elementary school education (29\%); and are the mothers of the users (61.4\%). Context and socioeconomic situation: they have an average of 3.78 family members; with an average family income of $R \$ 1,473.13$; most of them live in drug trafficking territory (93.1\%); live in their own house (77\%); and have minimum infrastructure conditions, such as a sewage system (99\%) and paved streets (99\%).

Regarding the profile of drug users, $56.4 \%$ have a history of alcohol and/or other drug use. Health history: $68 \%$ have already been under monitoring for addiction in the Psychosocial Care Center - CAPS or in therapeutic communities; $25 \%$ have other psychiatric comorbidities in addition to addiction; and $86.1 \%$ have a history of physical aggression against family members. Typical behaviors of harmful drug use: $54.3 \%$ of users usually stay in street situation; $47.9 \%$ practice theft; $29 \%$ commit robbery to maintain the use of drugs; $51.6 \%$ stay some days away from home; and $50 \%$ have criminal history as a result of the harmful use of drugs.

After the analysis of the interviews, the classification was made in the following categories: 1 . the difficult coexistence with the user; 2 . the family members' path to "bring the user back to life"; and 3. family members' expectations and needs regarding compulsory internment.

\section{The difficult coexistence with the user}

The participants reported difficulties in living with the user, showing communication problems and his aggressiveness due to substance use. They also pointed out difficulties of dialogue with the drug dependent member, emphasizing that they felt bewildered without knowing what to say and how to deal with the situation.

So, at the time, he was very unhinged and there were problems at home between us and him... When a person is out of his mind, he doesn't measure what he does, his mind was out... my mother was sick [cancer] like that, my mother suffered [...] seeing my mother suffer, we suffered more [...] then I said, let's do what [...]. (Amethyst Family - M, brother)

In the attempt to search for problem-solving strategies, family members do not perceive themselves as part of the problem, but see the drug addict as a "problem-subject".

[...] Because it depends on him, not on us [...] Because it depends on the personality of the person. (Emerald Family - I, sister)

Likewise, they feel tired with the constant relapses and don't know what to do, but they believe in recovery.
[...] And I believe that he will get tired, he will be overcome by tiredness [...] imagine us, we are also tired of suffering [...]. (Jasper Family - S, mother)

In the face of these difficulties, family members come to believe that hospitalization is a viable alternative to improve the routine of the home.

[...] We needed to get him out of the house, because he was putting the family at risk, affecting the whole dynamic of the house, not letting anyone sleep [...]. (Ruby Family - SM, mother)

\section{Familiar's journey to "bringing the user back to life"}

The family members interviewed reported going through a journey whose goal was to "bring the users back to life". They pointed out that the users started living as a function of psychoactive substances to the detriment of life projects, such as family, professional career, and social life. They also believe that a job and responsibilities are important elements in the process of managing drug addiction.

[...] I wanted him to be able to work, but not for my benefit, for his own, right? [...]. (Turquoise Family - B, daughter)

[...] Hence this part, I wanted him to live again, a job, I don't know, I wanted him to be a man again. (P, son)

Another relevant issue is the obstacles related to access to health care. They show disbelief in the psychosocial care network available and begin to see in the justice system the possibility of operationalizing the desire/willingness/desire for hospitalization, in a complex movement of judicialization of health policy. They also expressed difficulties of access to the network of drug services, such as bureaucracy and lack of reception of users and family members.

[...] llooked for compulsory internment for him, I talked to him at the beginning, and he even agreed and said he would, but what happens, for this to happen there, there are a lot of procedures, you have to go through a certain type of monitoring [...] so l looked for the Public Defender's Office because it was the only way out I had, where else would Ilook, there is nowhere else to look [...] if he was in a place where it was closed, where there is a regime, a discipline to be followed, I believe that by going through a treatment like this he would have [...]. (Topaz Family - DD, brother)

They emphasized that the slowness of the services and the difficulties in access to health care contributed to the fact that the family members saw in the judiciary and also attributed to it a power to change by means of force, including even the use of violence.

Because if the state, the rulers, see that the situation of the people is like this, from here to worse... why don't they take action before? [...] my mother went to the Public Defender's Office in April last year, so far nothing has been solved, there were visits to see if they could take us to CAPS. [...] Paper accepts everything, if the judge doesn't tap the pen, nothing solves. (Emerald Family - I, user's sister) 
You have to take it and beat him [...] Give him a beating every day [...] For me he is not worth anything [...] He never accepted treatment, he has been using drugs since he was twenty-something, his uncles found out, they already paid for a clinic, they threatened him that if he didn't go, he would lose his job, they gave him a job, so he went [...] Calmly, it doesn't work, you have to beat him up. (Onyx Family - C, brother)

The speeches brought up a need for a more integral health care.

They told us to participate in the family program [CAPS AD family groups], then I arrived there, the girl called me and asked me what was happening, then I told the problem, then, after 5 minutes, the girl said "okay" and dismissed me [...] until one day, there was a meeting of several people, there were about ten people, then they asked: "Mr. $G$, what is your problem? Then I told them about my problem, then she said "You are dismissed", and I left [...] then I went once, twice, I wasn't solving it, I didn't go anymore. (Pearl Family - G, father)

\section{Family members' expectations and needs regarding com- pulsory internment}

The family members create in the compulsory internment an ideal to solve all the problems and keep the family member abstinent, aiming to change the lifestyle through an authority external to the family system.

I really needed this hospitalization [...] to see him quit drinking [...] to be a man, not to give us any trouble [...] before I die, I want to see him quit drinking. (Diamond Family - C, mother)

[...] to be able to arrive at his house, see him well, without drinking [...]. (G, user's son)

Although the addict had been hospitalized other times, and relapsed, the family members hope that, with the intervention of justice, "this time it can be different.

My expectation was always that he would get better, but I know that alone he won't be able to do it [...] So, when I searched, my expectation was another hope in relation to help with doctors, detoxification that he has already gone through [...]. (Jasper Family - N, sister)

We really needed [...] to see him [...] be a man, go back to work, not give us work [...] We want a better life, you know, to be able to go to his house and see him well [...] it's not the same as before... the good life we had before [...] To see him well only, you know, like him having a better life. (Diamond Family - C, mother)

Facing the suffering that involves the dynamics of drug addiction, family members seem to cling to the belief that hospitalization will bring improvement, or solution, to the problems. The family members have the expectation that the justice system will be able to operate changes, to sensitize their loved ones to drug addiction, so that they can mobilize for treatment and overcome their condition.

[...] / wish they would call me, him and his mother to face the judge and explain the truth to him, give him a chance, say "D. it's going to be like this, I'll give you a chance, if you repeat the same acts, the judge will say, I'll take action, then I don't know what action the judge will take [...] then he might have a little fear in front of a judge [...]. (Pearl Family - G, father)

\section{DISCUSSION}

Knowing the characteristics of the families of drug addicts and the reflections of such condition in the family dynamics is of utmost relevance to design broader and more efficient treatments and thus build health policies able to fully support the real needs of this population, since such a problem makes them more vulnerable and in need of attention and peculiar care that transcend the linear view of the problem ${ }^{(13-16)}$

The data revealed vulnerable family systems, in intense distress, fragile, with family histories of drug use, as well as previous and recurrent hospitalizations.

The literature shows compulsory internment as a State strategy for the exercise of social control over human life, through actions that are implemented and naturalized in the societal locus, including interventions that meet the interests of the status quo, legitimized in legislation and printed in drug policies ${ }^{(17)}$. Thus, the judicialization of health care seems to function as a mechanism of surveillance and control of users, in this view, "unable" to promote their self-care ${ }^{(17)}$. These questions listed by the authors present themselves as an invitation to critically reflect on compulsory internment as a very exceptional measure and praxis capable of demystifying what is naturalized by the dominant view ${ }^{(17)}$. Thus, based on such questions, it is necessary to broaden the view about the theme, of ways of life that may be different from the politically acceptable for the maintenance of "social order", aiming to transcend positivist, univocal and conservative ideas about drugs, family and society.

The profile found is similar to those of the National Survey of Families of Drug Addicts (LENAD). In both, the woman is the protagonist in dealing with drug addiction and caring for her loved one ${ }^{(16)}$. Observing the suffering itinerary of these family members, mothers mostly assume this role of care before the impact of the role that drugs assume in this context surrounded by absences and difficulties. They can't deal alone with so many daily issues, such as intra-family violence, with drugs as a trigger, besides the parallel power in the territory, lack of material resources and access to health care policies. Here appears a gender issue, which should be further investigated in subsequent studies. Moreover, the speeches of these mothers are full of affection and, many times, affected by the manipulative and seductive behavior of the drug addict, making it difficult to establish a limit for the abusive behavior. Moreover, such dynamics imprints the androcentric vision in which the woman is placed in a place of subservience.

When looking at the reports and the literature, it was realized that the routine of family members in the dynamics of drug abuse is stressful and painful, because it brings enormous material and subjective losses. Besides the daily shock, some areas of family life suffer important impacts, such as the financial sphere, rituals, routines, communication, and social life ${ }^{(4,13-18)}$.

Regarding the economic situation, the families participating in the study are considered financially hypo-sufficient, with an average 
family income of $R \$ 1,473.13$. Thus, it is possible to infer that the financial stress culminated by the cycle of drug addiction generates expectations of accessing this care through private clinics; however, due to the lack of economic resources, family members resort to compulsory hospitalization. This is not different from another study conducted with family members, which pointed out that $45.4 \%$ of them had their finances drastically affected ${ }^{(13)}$. The literature reveals that chemical dependence causes losses and financial difficulties for the family, in addition to weakening family relationships and generating physical and psychological burden for caregivers, so that living with a chemical dependent causes different losses: besides affecting the economic situation, it has repercussions on family and social relationships ${ }^{(1-4,14)}$.

The results brought an important statistic regarding family history of drug use and are in line with the latest $L E N A D$ survey, which points out that $61.6 \%$ of people have a history of other family members with drug use. Moreover, inter-generationality is also a factor that influences chemical dependence ${ }^{(14,16)}$. Because of this, dealing with such a problem requires a reorganization of the family at every moment. This leads to the tightening of the bonds of trust in the intra-family relationship, which causes exhaustion in the relationship and leads to feelings of insecurity and helplessness ${ }^{(1-2,16)}$.

With regard to the vulnerability of the territory where they live, the majority of family units are concentrated in places under strong drug trafficking control. These data corroborate the studies in which it was demonstrated that socially vulnerable territories increase the risk of exposure to drugs, fostering recursion through cyclical and imitative behaviors. Also, the power relations orchestrated by criminal groups linked to drug trafficking affect significantly all families living in the territory, providing a naturalization of authoritarian patterns and norms, in addition to making violence and drugs part of everyday life $\mathrm{e}^{(13-16,18)}$. The literature reveals that $59 \%$ of drug users live with their families; in this sense, being the family an important microsystem that forms values and rules for social insertion, it configures itself as a rich relational ground capable of promoting protection or lack of protection ${ }^{(13-16,18-19)}$.

With regard to the history of hospitalizations, the findings of this study confirm research according to which a large proportion of users who undergo compulsory hospitalization already have previous hospitalizations. This is the phenomenon of readmissions, known in the literature as "revolving-door" or "revolving-door"(19-20). Regarding health history, our results align with the data from Family $L E N A D$, which indicate that $62 \%$ of users have been in therapeutic communities and $33 \%$ in clinics and day hospitals ${ }^{(16)}$.

Regarding the low percentage of comorbidities that appeared in the results, the literature confirms such data in most cases, since the fact that the individual lives in function of the drug and does not access health services makes it difficult to diagnose clinical comorbidities and care, showing a social isolation and other difficulties arising from drug addiction, resulting in difficult access to health care ${ }^{(21)}$.

Other data that drew attention were the variables exposing high levels of aggressiveness and criminal history as a result of harmful drug use. Thus, there was a significant association between the applicant for hospitalization and the presence of aggressiveness, also found in the literature. As the experience of aggressiveness is a reality present in the dynamics of drug addiction, violence should not be understood as an isolated aspect, since it is an issue with biopsychosocial dimensions, so that the association between aggressiveness and drug use has contributed to compulsory hospitalizations ${ }^{(21-24)}$.

Although the literature on chemical dependence reveals the importance of the family as a protective factor in the dynamics of this condition, in general, the therapeutic modalities for its management and re-signification do not contemplate the family insertion and, much less, provide a reflection that provokes changes in family patterns that contribute to the condition of drug abuse. However, it is noteworthy that, historically, the family has been placed as a supporting actor in the treatment of addiction, for being considered an important link between users, their various social contexts, and care equipment ${ }^{(16,24)}$.

The results found in this study highlight the needs of family members to deal with drug addiction. Thus, they saw in the justice system, through the request for compulsory internment, a possibility to get help and care to face drug addiction.

It is believed that the movement of families to seek help and care in the justice system reflects the systematic and wide lack of policies of attention to drug addiction, capable of meeting the real needs of the subjects involved in this plot, making them seek in other instances what they did not find in the network of care operating in the territory in which they are inserted. It would be, then, the search for a care that values empowerment, inter-subjectivities, the narratives of the subjects, and the ability to co-construct solutions based on the relativism of truths before the complexity of the issue that transcends linear solutions ${ }^{(15,24-26)}$.

Thus, studies show that when the family is included, the addict has greater adherence to treatment. They also point to the scarcity of scientific knowledge production aiming at viable strategies of attention to family members that transcend group, educational, and sheltering spaces, based on the assumption that it is in the family that protection is processed. Thus, such subjects need to be empowered, including emotionally, in order to, in addition to strengthening bonds, deal with problems and conflicts that arise from the dynamics of addiction, to rescue their protagonism ${ }^{(24-27)}$.

It is imperative to establish new mechanisms to approach the family, since in order to understand their needs, it is necessary to go beyond the walls of the service and participate in their daily lives in the territory, because it is mainly outside the institution that individuals are outlined. This, because their relationships are made up in the spaces in which they circulate, so that, outside the institutional rigidity, subjects can be seen in their singularity, enabling a better reception of their needs and the search for joint solutions to their pains and fractures ${ }^{(21,24,28)}$.

Instruments, such as home visits and territorial actions in the world of families, enable a better understanding of the user in his context. Studies show these strategies transcend the ideology of the disease, because they allow a social and emotional approach to the problem ${ }^{(24-28)}$.

This allows us to draw a more concrete guideline, connected to real health needs, seeking singularities in the form of care, recognizing the space of the family home as a place of mental health.

In this logic, users need to be seen beyond the stigma of a mental health diagnosis, in which "life is pathologized". Although 
from a legal point of view compulsory internment is considered an exceptional measure, it seems to serve on a daily basis to fill gaps in health care and promotion policies, as well as to discipline lifestyles alienated from their ethical-political process.

Another relevant question about health care is the management tools used for a silent dismantling of public policies and removal of state protection to give way to a process of mercantilization of health ${ }^{(17)}$. Difficulties in interdisciplinary work, dismantled and overcrowded health services, professional unpreparedness to deal with family members, welcoming focused on addiction and drug users, and the absence of a well-structured care network are items that hinder the comprehensive care, and it is believed that drive family members to see the justice system as a possibility to realize their need for help and care to contain the suffering experienced $(21,24,28)$.

Several studies, both theoretical and those that guide practice, point to the need for collaborative interventions in sustainable, co-participative and constructed networks, as well as the Expanded Clinic model ${ }^{(24-27)}$. This model values interdisciplinary work and intersectoral networks. It is a way of doing things that proposes a systemic look, that is, a broader look at the issue, transcending drug therapy, because it includes the power of narratives, interdisciplinary listening, health education, and psychosocial support, horizontalizing the clinic in a dimension of comprehensive care of the subjects, without losing sight of their territorial, social, economic, cultural, and political context. The subjects must be placed in a place of participation and collaboration for the joint construction of paths, which implies expanding concepts such as health, disease, treatment, autonomy and rights to better encompass the complexity of this phenomenon ${ }^{(27)}$.

The results of this study showed that family members have expectations of "bringing the user back to life" because, as a result of drug use, they have left important projects aside, as well as the expectation that their dependent family member has awareness about himself and the dependency. They nurture the belief that the justice system can contribute to improving self-criticism and overcoming addiction through judicial internment, and thus recover life projects once left behind, such as starting a family, reestablishing emotional relationships, professional projects, and social life. The itinerary of suffering of these family members when trying to "bring their loved one back to life" drew attention, since it was perceived the experience of mourning for the loss of "who the user was before the drug" and how he is in the present daily use. They expect to "make the user go back to the way he was before", as if this were possible, because after some experiences that have changed reality, there is no way back to the past, but to build new paths, which can be good or bad, depending on the point of view.

The difficulties of drug addicts to follow up on projects, to establish or maintain relationships are expected, since such consequences are part of the dynamics of abuse, once they start living as a function of psychoactive substances ${ }^{(21,24)}$. With regard to occupational status, surveys show that most users remain unemployed $^{(21,24)}$. Family members have shown expectation that the justice system can contribute to their loved one to give new meaning to his or her process of drug abuse, believing that the judicialization of the issue could provoke self-reflection and an awareness of the need for treatment and change of life. In this context, a study shows the expectation of family members in the protagonism of the user as a predictor of treatment success ${ }^{(4)}$. A relevant point was the fact that family members, in their narratives, see the user as a problem-subject and do not see themselves as participants in the dynamics of addiction.

Indeed, such movement of judicialization of life, specifically of health care policy, presents itself as a phenomenon that requires a discerning and reflective look. As to the aforementioned issue, research has debated controversial aspects of compulsory internment, in order to create transition models capable of fostering a substitute health network to fully assist users and their families, since it has been perceived the ineffectiveness of compulsory treatment compared to voluntary treatment, which shows better results, as explained in the literature ${ }^{(5,20-28)}$.

Another expectation that emerged was that, with the improvement of the condition, the dependent family member would be able to remain abstinent. Taking as a starting point the complexity that involves drug addiction and the singularity of the subjects, it is known that the logic of abstinence may not meet the real needs and possibilities of the dependent family members.

In this reasoning, abstinence is presented as a myth, amid the pain of fear of loss, seeming to make the family incorporate a reactionary and conservative discourse on dealing with drug addiction. Such discourse can be understood as a manifestation of the understanding that the drug is the problem and not the symptom of a wider and more complex phenomenon.

Families, in general, bring a burden of problems and arrive full of expectations and needs when they enter the justice system. When they arrive, the great challenge is to work against the judicialization of life and health, welcoming and empowering this group to become involved and to perceive themselves as co-responsible for the problem and, therefore, co-participants in the construction of ways to deal with it.

From this perspective, we reflect against the procedural rites, but seeing the right in its broadest sense, to fully access the policies of protection and care, building together, based on the triad "familyjustice system-health care policies", a path to overcome, in which the user, instead of being the "problem-subject", needs to be seen as part of a system that interacts with its environment and its subjectivities.

The experience of this interdisciplinary praxis has contributed to the expansion of the look to the singularity of these family systems, demarcated by the drug cycle, in a way that allows welcoming, better understanding of specificities, qualified listening and co-construction with the families of possible strategies of attention and daily care of their demands. Thus, it contributes to the empowerment of these family systems, in their important role as protagonists of their historical family process of re-signification of life in the face of drug problems. Finally, it is urgent to build wider therapeutic projects, so that they include, besides the family, people who surround the user in the community. The families studied showed a need for a sensitive look at their specificities, capable of generating professional interventions that provide help, care, and protection for the completeness of health care.

The results found corroborate national and international studies on the subject, especially regarding the magic way out of the problem by judicializing the demand for health care and the search for care after enduring intense suffering resulting from criminalization and violence as consequences of drug addiction. 
They also showed an intense suffering of family systems, caused by the drug cycle, in a way that their search for help in the justice system is not by chance, on the contrary, it is the result of a series of determining factors of a search for help loaded with absences and punctual services that do not seem to contemplate singularities, expectations and specific needs of such families.

\section{Study limitations}

As a limitation of the study, it was conducted in a single context of legal assistance to families of drug users in a unit of the Public Defender's Office in the interior of the state of São Paulo. Therefore, it is suggested that the study be expanded to deepen the understanding of the profile, expectations, and needs of families who seek compulsory hospitalization for their drug-dependent family member.

\section{Contributions to the field of Nursing, Health or Public Policy}

The study presents contributions to the area of Nursing, Health and Public Policy, as it enables reflection on the relevance of creating a space for listening and understanding the family system in inter-professional care, strengthening it for the resolution of health problems related to drug addiction, with the uniqueness of individuals and families as the common thread.

\section{CONCLUSION}

This study provided the broadening of the professional view to the complexity and inter-subjectivities of family systems in the face of the drug cycle. From this perspective, it was observed the importance of respecting the singularity of family systems, allowing the expression of their expectations and needs, to provide the help and care needed to face drug addiction.

Although families experience situations of vulnerability in drug dependence, it is important to value their competencies to face situations of risk related to the problem. Families create expectations about compulsory hospitalization, but this exceptional measure should be the last resource for care and protection of the health of the drug dependent family member. Thus, it becomes relevant to promote discussions and construction of interdisciplinary strategies in the comprehensive care of these families.

\section{REFERENCES}

1. Siqueira DF, Terra MG, Vieira LB, Mello AL, Moreschi C, Soccol KLS. Care actions for family members of users of psychoactive substances: intentions/expectations. Rev Bras Enferm. 2018;71(Suppl 5):2221-8. https://doi.org/10.1590/0034-7167-2018-0027

2. Rodrigues TFCS, Sanches RCN, Oliveira MLF, Pinho LB, Radovanovic CAT. Feelings of families regarding drug dependence: in the light of comprehensive sociology. Rev Bras Enferm. 2018;71(Suppl 5):2272-9. https://doi.org/10.1590/0034-7167-2018-0150

3. Dias CRI. Percepção do suporte familiar, autoeficácia e estágio motivacional: implicações na assistência ao usuário de crack [Dissertação] [Internet]. Recife: Universidade Católica de Pernambuco; 2017 [cited 2020 Jun 22]. Available from: http://tede2.unicap.br:8080/handle/tede/251

4. Elvira IKS, Reis LM, Gavioli A, Marcon SS, Oliveira MLS. Esperança de famílias que convivem com comportamento aditivo por tempo prolongado. Rev Enferm Cent Oeste Min. 2019;9:e3241. https://doi.org/10.19175/recom.v9i0.3241

5. Paula CEA, Silva LHFP, Bittar CML. Judicialização da Saúde: perspectiva dos operadores do direito, gestores e usuários. Saúde Transform Soc [Internet]. 2019 [cited $2020 \mathrm{Jul}$ 20];10(1):52-4. Available from: http://incubadora.periodicos.ufsc.br/index.php/saudeetransformacao/article/ view/5254

6. Creswell JW. Research design: qualitative, quantitative, and mixed methods approaches. 4 thed. Los Angeles: University of NebraskaLincoln; 2014. 342 p.

7. Oliveira JLC, Magalhães AMM, Matsuda LM. Métodos mistos na pesquisa em enfermagem: possibilidades de aplicação à luz de Creswell. Texto Contexto Enferm. 2018;27(2):e0560017. https://doi.org/10.1590/0104-070720180000560017

8. Galvão MCB, Pluye P, Ricarte ILM. Métodos de pesquisa mistos e revisões de literatura mistas: conceitos, construção e critérios de avaliação. InCID. 2017;8(2):4-24. https://doi.org/10.11606/issn.2178-2075.v8i2p4-24

9. The EQUATOR Network. What is a reporting guideline? [Internet]. 2020[cited 2020 Aug 28]. Available from: http://www.equator-Network. org/about-us/what-is-a-reporting-guideline/

10. Santos JLG, Erdmann AL, Meirelles BHS, Lanzoni GMML, Cunha VP, Ross R. Integração entre dados quantitativos e qualitativos em uma pesquisa de métodos mistos. Texto Contexto Enferm. 2017;26(3):e1590016. https://doi.org/10.1590/0104-07072017001590016

11. Minayo MCS. O desafio do Conhecimento-Pesquisa Qualitativa e Saúde. São Paulo/Rio de Janeiro: Hucitec-Abrasco,14 ed. 2014.

12. Santos FM. Análise de conteúdo: a visão de Laurence Bardin [Resenha]. Rev Eletrôn Educ [Internet]. 2012 [cited 2020 Jun 20];6(1):383-7. Available from: http://www.reveduc.ufscar.br/index.php/reveduc/article/view/291/156

13. Duarte MLC, Pereira LP, Carvalho J, Olschowsky A. Evaluation of families of crack users in relation to support groups. Rev Bras Enferm. 2018;71(Suppl 5):2184-90. https://doi.org/10.1590/0034-7167-2017-0808

14. Santana CJ, Oliveira MLF. Effects of drug involvement on long-term users' family members. Rev Rene [Internet]. 2017 [cited 2020 Aug 20];18(5):671-8. Available from: http://www.periodicos.ufc.br/rene/article/view/30844/71503

15. Silva JDA, Comin FS. Families may (themselves) become ill: an integrative review of the scientific literature. Vínculo [Internet]. 2019 [cited 2020 Aug 20];16(2):23-43. Available from: http://pepsic.bvsalud.org/pdf/vinculo/v16n2/v16n2a03.pdf 
16. Laranjeira R, Sakiyama H, Padin MFR, Madruga CS, Mitsuhiro S. Levantamento Nacional de Famílias dos Dependentes Químicos (LENAD Família) São Paulo: Instituto Nacional de Ciência e Tecnologia para Políticas Públicas de Álcool e Outras Drogas-Universidade Federal de São Paulo (INPAD- UNIFESP) [Internet]. 2014 [cited 2020 Aug 20]. Available from: https://inpad.org.br/lenad

17. Guareschi NMF, Lara L, Ecker DD. A internação compulsória como estratégia de governamentalização de adolescentes usuários de drogas. Estud Psicol. 2016;21(1). https://doi.org/10.5935/1678-4669.20160004

18. Instituto Brasileiro de Geografia e Estatística (IBGE). Pesquisa Nacional de Amostra de Domicílios. [Internet]. 2018 [cited 2020 Aug 20 ]. Available from: https://biblioteca.ibge.gov.br/visualizacao/livros/liv101548_notas_tecnicas.pdf

19. Lazari AH, Hungaro AA, Okamoto ARC, Suguayama P, Marcon SS, Oliveira MLF. Famílias em território vulnerável e motivos para o não uso de drogas. Rev Eletrôn Enferm. 2017;19:a11. https://doi.org/10.5216/ree.v19.38380

20. Silva JRF, Penso MA. Readmissão por dependência química: análise documental em clínica psiquiátrica. Rev Med Saúde Brasília [Internet]. 2019 [cited 2020 Aug 28];8(2):156-168. Available from: https://portalrevistas.ucb.br/index.php/rmsbr/article/viewFile/10803/6626

21. Lucas LGQ. Caracterização de usuários de substâncias psicoativas e motivos para internação compulsória [Dissertação] [Internet]. Escola de Enfermagem de Ribeirão Preto. Universidade de São Paulo, 2017 [cited 2020 Mar 28]. Available from: https://teses.usp.br/teses/ disponiveis/22/22131/tde-25012018 100157/publico/LUIZGABRIELQUINZANILUCAS.pdf

22. Barbieri RS, Wesendonck A, Fensterseifer CC, Pulcherio D. Vulnerabilidade Social e criminalidade associada ao uso de drogas: um análise do município de Frederico Wesphalen-RS. Rev Gedecon [Internet]. 2019 [cited 2020 Aug 28];7(1):72-92. Available from: http:// revistaeletronicaocs.unicruz.edu.br/index.php/GEDECON/article/download/8115/2023

23. Pereira LFG, Ricardo IM, Aquino RL, Xavier DAA. Internação compulsória de dependentes químicos: violação do direito de liberdade ou proteção do direito à vida? Hygeia [Internet]. 2020 [cited 2020 Aug 28];16:11-24. Available from: http://www.seer.ufu.br/index.php/hygeia/ article/view/47423/28909

24. Cavaggioni APM, Gomes MB, Rezende MM. O tratamento familiar em casos de dependência de drogas no brasil: revisão de literatura. Mudanças. 2017;25(1):49-55. https://doi.org/10.15603/2176-1019/mud.v25n1p49-55

25. Zerbetto SR, Galera SAF, Ruiz BO. Family resilience and chemical dependency: perception of mental health professionals. Rev Bras Enferm. 2017;70(6):1184-90. https://doi.org/10.1590/0034-7167-2016-0476

26. Tessaro D, Schimidt B. Escolha profissional: teoria e intervenções sistêmicas voltadas ao adolescente e à família. Pensando Fam [Internet]. 2017 [cited 2021 Jan 18];21(1). Available from: http://pepsic.bvsalud.org/pdf/penf/v21n1/v21n1a08.pdf

27. Taveira GMM, Neiva GSM, Vilela RQB, Lucena Neto PB. Clínica ampliada: conhecimento de alunos de medicina. Rev Port Saúde Soc [Internet]. 2019 [cited 2020 Aug 28];4(2):1086-95. Available from: https://www.seer.ufal.br/index.php/nuspfamed/article/viewFile/7401/6365

28. Campos DB, Bezerra IC, Jorge MSB. Produção do cuidado em saúde mental: práticas territoriais na rede psicossocial. Trab Educ Saúde. 2020;18(1):e0023167. https://doi.org/10.1590/1981-7746-sol00231 